\title{
Investigator Signature
}

National Cancer Institute

\section{Source}

National Cancer Institute. Investigator Signature. NCI Thesaurus. Code C70947.

A textual or multimedia form of the signed name or personal mark of the investig ator who is responsible for completing a particular document as a part of clinical study activity. By signing this document the investigator confirms his participation and his role in the study and assumes responsibility and accountability associated with this role. 